\title{
Cell Separation by Density Gradient Centrifugation
}

National Cancer Institute

\section{Source}

National Cancer Institute. Cell Separation by Density Gradient Centrifugation. NCI

Thesaurus. Code C112934.

A method of separating cells by either their differential rate of sedimentation in a centrifugal gradient or their differential buoyancy in a density gradient. 